\title{
Moral Politics: The Religious Factor in Referenda Voting
}

\author{
Carolin Rapp \\ University of Bern
}

Richard Traunmüller

University of Essex

\section{Markus Freitag}

University of Bern

\section{Adrian Vatter \\ University of Bern}

\begin{abstract}
This article combines the research strands of moral politics and political behavior by focusing on the effect of individual and contextual religiosity on individual vote decisions in popular initiatives and public referenda concerning morally charged issues. We rely on a total of 13 surveys with 1,000 respondents each conducted after every referendum on moral policies in Switzerland between 1992 and 2012. Results based on crossclassified multilevel models show that religious behaving instead of nominal religious belonging plays a crucial role in decision making on moral issues. This supports the idea that the traditional confessional cleavage is replaced by a new religious cleavage that divides the religious from the secular. This newer cleavage is characterized by party alignments that extend from electoral to direct democratic voting behavior. Overall, our study lends support to
\end{abstract}

Address correspondence and request for reprints to: Carolin Rapp, University of Bern, Institute of Political Science, Fabrikstrasse 8, 3012 Bern, Switzerland. E-mail: carolin.rapp@ipw.unibe.ch; Richard Traunmüller, University of Essex, Department of Government, Wivenhoe Park, Colchester CO4 3SQ, United Kingdom. E-mail: r.traun@essex.ac.uk; Markus Freitag, University of Bern, Institute of Political Science, Fabrikstrasse 8, 3012 Bern, Switzerland. E-mail: markus.freitag @ipw. unibe.ch; Adrian Vatter, University of Bern, Institute of Political Science, Fabrikstrasse 8, 3012 Bern, Switzerland. E-mail: adrian.vatter@ipw.unibe.ch. 
previous findings drawn from American research on moral politics, direct democracies, and the public role of religion.

\section{INTRODUCTION}

Is it right to end a pregnancy prematurely? Are people in same-sex relationships entitled to the same rights and privileges as heterosexual couples? Or is deviant behavior such as taking drugs or heavy drinking justifiable at any time? Although some would argue that public attitudes concerning these moral issues have become increasingly liberal over the last few decades, religion continues to play a pivotal role in the formation of core values and beliefs of what is right or wrong (Flanagan and Lee 2003; Inglehart and Baker 2000; Minkenberg 2002; Toft et al. 2011). Numerous studies have highlighted the importance of religious forces in explaining moral policy outcomes (Donovan et al. 2008; Fairbanks 1978; Feddersen et al. 2009; Fink 2008; Haider-Markel 2001; Hutcheson and Taylor 1973; Minkenberg 2002; Morgan and Meier 1980; Olson et al. 2006; Roh and Haider-Markel 2003). These studies have scrutinized the effects of religion at the state level (e.g., Morgan and Meier 1980), religious orientations in parliaments (Haider-Markel 2001), the influence of religious groupings and predominant churches on legislating abortion, homosexuality, or gambling (Fabrizio 2001; Olson et al. 2006), or the differences in moral policy legislature across nation states and religions (Engeli 2009; Fink 2008; Schiffino et al. 2009).

Moral issues and their connection to religiosity have recently also attracted considerable attention in the study of political behavior. Heated debates in the United States revolved around the so-called culture wars, pitting orthodox and progressive groups against one another on moral issues such as abortion, gay rights, or family values. This culture war resulted in a striking religious gap in the 2000 and 2004 presidential elections (e.g., Campbell 2007; Donovan et al. 2008; Fiorina 2005; Green 2010; Hunter 1991; Layman and Green 2005). In Europe, scholars have focused renewed interest on the stability and change of the traditional religious cleavages that once shaped the formation of party systems and that continue to structure mass electoral behavior in many European countries (e.g., Ackermann and Traunmüller 2014; Brooks et al. 2006; Elff 2007; Essmer and Pettersson 2010; Knutsen 2004; Minkenberg 2010).

In this study, our aim is to combine these two research strands of moral politics and political behavior by focusing on the effect of individual and contextual religiosity on individual vote decisions in popular initiatives 
and public referenda concerning morally charged issues, such as abortion or drug abuse. Although these issues are highly salient to the public and many countries beyond the United States legislate moral issues through direct democratic instruments (e.g., Italy, Ireland, Portugal, and New Zealand), explanatory factors which could explain citizens' vote decisions on these issues have, for the most part, been neglected in empirical research.

The present study expands existing research on religion and moral policies in two important ways. First, we depart from the traditional policybased research field of moral politics. Most of the research in this field has focused exclusively on the policy-making process or the framing of moral issues on various levels, such as the parliament or the federal and the subnational levels of government (Engeli and Varone 2011; HaiderMarkel 2001; Mooney and Lee 2001; Morgan and Meier 1980). While this certainly is where policy-making and legislating mainly takes place, this is not true for countries offering a wide range of direct democratic instruments where the citizens decide on laws and regulations. Although here citizens' characteristics may play a crucial role in decisions to liberalize or restrict moral policies, the extant research has focused primarily on state-level attributes in explaining variations in moral policy outcomes in public referenda and initiatives (see Fairbanks 1977; Morgan and Meier 1980). In contrast, we focus on the effects of individual-level attributes and attitudes, particularly religious belonging and behaving, for the liberalization of moral issues. In addition, we further consider possible contextual-level religious factors, such as the prevalence of Catholicism on the cantonal-level and the party paroles on the vote-specific level that may influence the relation between individual religiosity and voting decisions on moral issues.

Second, we add a new perspective on the relationship between direct democracy and moral politics by extending existing research on the United States to another country with well-established direct democratic instruments, namely Switzerland. Although Swiss direct democracy differs from what is practiced in the United States, as it is not limited to the state or local level but is practiced at all federal levels, both countries are very similar with regard to their long-lasting experience, extensive use as well as their specific types of direct democratic instruments, such as the referendum and popular initiative (Linder 2010, 162). Moreover, the United States and Switzerland are often declared as "Sister Republics" due to their enduring republican system as well as their extensive federalist structure (Hutson 1991). In the past, Switzerland has held a wide range of 
national referenda and public initiatives on moral issues and may therefore be regarded as an exemplary case for assessing direct democracy's effect on moral policy.

Moreover, Switzerland is characterized by a strong traditional confessional cleavage between reformed Protestantism (initiated by Zwingli and Calvin in Zurich, Geneva, and Bern) on the one hand and Catholicism (in the rural cantons of central Switzerland) on the other. This confessional divide between Protestants and Catholics was once the source of considerable conflict and continues to play a decisive role in party identification and voting behavior, such as Catholics' preference for the CVP (Christ-Democratic Popular Party) (Geissbühler 1999; Geser, 1997; Kriesi and Trechsel 2008; Lachat 2012; Lijphart 1979; Linder 2010; Voll 1991). The mechanisms and individual factors explaining vote decisions for political candidates or party programs in elections do not however necessarily overlap with the factors influencing vote decisions on specific policy questions in referenda. In fact, it has been argued that political loyalties based on the traditional confessional cleavage may be stronger and more durable for party identification and more volatile in terms of direct democratic voting behavior (Voll 1991, 379).

Methodologically, we rely on a total of 13 surveys with approximately 1,000 respondents each conducted after each referendum on moral policies in Switzerland between 1992 and 2012. The information provided by these surveys allows us to investigate individual political behavior concerning moral issues in great depth. By going beyond the effect of moral issues on voter turnout (Biggers 2011; Tolbert et al. 2005), we not only further the research on moral policies and direct democracy, but also investigate the origins of liberalized moral policies reached through direct democratic means and what role the religious factor plays in decision-making.

We proceed by outlining the key features of moral policies, focusing on how religion influences the liberalization of these policies. After defining our main research hypotheses, we present our data and methods. In the section to follow, we discuss our main results concerning individual religious behavior and the liberalization of moral policies. A discussion of these results and a conclusion finally complete the article.

\section{CONFLICTS OF BASIC VALUES - MORAL ISSUES}

Within recent years the clash of fundamental values regarding moral issues has fuelled heated public debates and scholarly research (Kirchner et al. 
2011; Knill 2013; Mooney 2001; Mooney and Schuldt 2008; Studlar 2001; Studlar et al. 2013). This clash of values revolves mainly around questions of first principles such as matters of life and death or deviant behavior. An issue is declared as moral as soon as one group feels its core values or belief system threatened by an issue. Moral issues are therefore primarily defined by their framing rather than by their mere content (Engeli and Varone 2011, 241; Mooney 2001, 3; Mooney and Schuldt 2008, 201; Meier 1994, 4). Mooney $(2001,4)$ further specifies that "a policy is classified as a morality policy based on the perceptions of the actors involved and the terms of debate among them." Against this background any issue may become morally charged as soon as it affects a group's core principles. Following the literature (especially Knill 2013; Mooney 2001; Mooney and Schuldt 2008; Studlar 2001; Studlar et al. 2013), the most common morally charged issues are abortion, euthanasia, homosexuality, and questions on drug abuse. ${ }^{1}$

Moral issues are further connected to three basic attributes: First, they are technically simple due to their straightforward conception of right and wrong (Mooney and Schuldt 2008, 201). Moral issues only allow two positions, being in favor or against it, whereas issues on taxation or economic matters allow positions between these two opposing poles. Additionally, moral issues are often framed in simple pictographic ways: there is the "sexual sinner" or the "irresponsible drinker" (see e.g., Engeli and Varone 2011, 241). Even rather technical issues such as stem cell research are easily understandable since they may be reduced to the question of life and death. Second, it is difficult to reach compromises on moral issues, as they concern issues of the heart and are constituted of two opposing positions. They comprise a zero sum game: a new regulation, the liberalization of abortion for example, allows a new set of values win; the old values are consequently defeated. Since they are based on the dichotomy of right and wrong, moral issues are thus not divisible (Engeli and Varone 2011; Mooney 2001). Third, due to their simplicity, moral issues are highly salient in public debates. Every citizen can easily build his or her opinion on these issues since there are only two possible positions. Along these lines, Grummel (2008) found that voter turnout is higher when moral issues are on the ballot. In this line, the turnout for the votes in our sample tends to be higher than in non-moral ballot votes. Moral issues are matters of the heart, which, by definition, are salient to the public and are decided on according to gut feelings.

The three above-mentioned features suggest increased difficulties in implementing decisions on moral issues, due especially to their high 
public salience and their indivisibility. Compared to non-morally charged policies, decisions on liberalizing or restricting moral policies are often more aligned to the prevailing public opinion (Camobreco and Barnello 2008; Mooney and Lee 2000; Mooney and Schuldt 2008). Consequently, moral issues frequently find their way onto the ballot, thereby leaving the decision process to the public (Biggers 2011). Politicians can easily withdraw from these highly conflictual issues and avoid playing a zero sum game with their voters (Tolbert et al. 2005). Despite this top-down decision-making process, groups that feel their core beliefs to be affected use popular initiatives, so-called bottom-up instruments, as a channel to enforce regulations on moral issues. According to Studlar (2001, 40), "moral issues are one of the major categories of issues subjected to initiatives and referenda where they are available."

For the case of Switzerland, the prototype of direct democracy, this means that the most important decisions on moral policies take place via public referenda and initiatives. Similar to the United States, Switzerland also offers direct democratic instruments at the subnational level, although most of the decisions on moral issues are made on the national level. And unlike in the United States, most of the issues may only be regulated on the national level in Switzerland (e.g., abortion or same-sex marriage). Regarding moral issues, we were able to identify 13 national moral initiatives and referenda that occurred between 1992 and the present in Switzerland (see Table 1 for more details).

As we and existing research in this field claim that moral issues are generally salient to the public, Figure 1 depicts the public and personal saliency of the respective moral ballot vote (on a scale ranging from 1 to 10). Overall we can see that the public salience on these issues is slightly higher in each of the 13 referenda for which data is available than the personal salience of the issue. Additionally, we took the turnout rates for these issues into account. The turnout gives a hint about the general saliency as more salient issues will draw more people to the ballot box (see e.g., Grummel 2008; Smith 2001; Tolbert et al. 2001). In general, the long-term average turnout rate for Swiss ballot votes is 45 percent (see Vox Analysis). Our selected moral issue votes, however, exhibit an average turnout of 50 percent for the 13 votes. These comparatively higher turnouts as well as the descriptive statistics in Figure 1 underscore the increased public saliency of morality issues at the ballot box in Switzerland. 
Table 1. Swiss Votes concerning moral issues (1992 - present)

\begin{tabular}{|c|c|c|c|c|c|}
\hline No. & date* & title & issue type & $\%$ yes votes & liberal/restrictive \\
\hline 513 & 28 Nov. 1993 & $\begin{array}{l}\text { Popular initiative on "the reduction of alcohol } \\
\text { problems" }\end{array}$ & addictive behavior & 25.25 & yes $=$ restrictive \\
\hline 516 & 28 Nov. 1993 & $\begin{array}{l}\text { Popular initiative on "the reduction of tobacco } \\
\text { problems" }\end{array}$ & addictive behavior & 25.51 & yes $=$ restrictive \\
\hline 621 & 28 Sept. 1997 & Popular initiative on "youth without drugs" & addictive behavior & 29.34 & yes $=$ restrictive \\
\hline 631 & 7 June 1998 & $\begin{array}{l}\text { Popular initiative on "the protection of environment } \\
\text { and life against genetic manipulation" }\end{array}$ & genetic engineering & 33.29 & yes $=$ restrictive \\
\hline 653 & 29 Nov. 1998 & Popular initiative on "a sensible drug policy" & addictive behavior & 26.01 & yes $=$ liberal \\
\hline 683 & 13 June 1999 & $\begin{array}{l}\text { Federal enactment on the medical prescription of } \\
\text { heroin }\end{array}$ & addictive behavior & 54.42 & yes $=$ liberal \\
\hline 694 & 12 March 2000 & $\begin{array}{l}\text { Popular initiative on "the protection of humans against } \\
\text { manipulations of reproduction technologies" }\end{array}$ & genetic engineering & 28.24 & yes $=$ restrictive \\
\hline 771 & 2 June 2002 & Swiss Criminal Code (abortion) & sexuality & 72.15 & yes $=$ liberal \\
\hline 772 & 2 June 2002 & $\begin{array}{l}\text { Popular initiative on "the protection of mothers in } \\
\text { need and protection of the unborn child's life" }\end{array}$ & sexuality & 18.25 & yes $=$ restrictive \\
\hline 863 & 28 Nov. 2004 & Federal Code on the research on embryonic stem cells & genetic engineering & 66.39 & yes $=$ liberal \\
\hline 872 & 5 June 2005 & Federal code on same-sex marriage & sexuality & 58.04 & yes $=$ liberal \\
\hline 974 & 30 Nov. 2008 & $\begin{array}{l}\text { Popular initiative on "a sensible cannabis policy with } \\
\text { an effective protection of the youth" }\end{array}$ & addictive behavior & 36.74 & yes $=$ liberal \\
\hline 975 & 30 Nov. 2008 & $\begin{array}{l}\text { Federal Code on narcotic substances and psychotropic } \\
\text { substances }\end{array}$ & addictive behavior & 68.07 & yes $=$ liberal \\
\hline
\end{tabular}

*Note: information was retrieved from http://forsdata.unil.ch/projects/Voxit/docu_xl_htmD/ListeVoxDispoD.htm?lang=d\&menu=4; The numbers refer to the numbering of the Voxit homepage; for the empirical analysis the votes were recoded so that a value of one always indicates a liberal voting decision. 


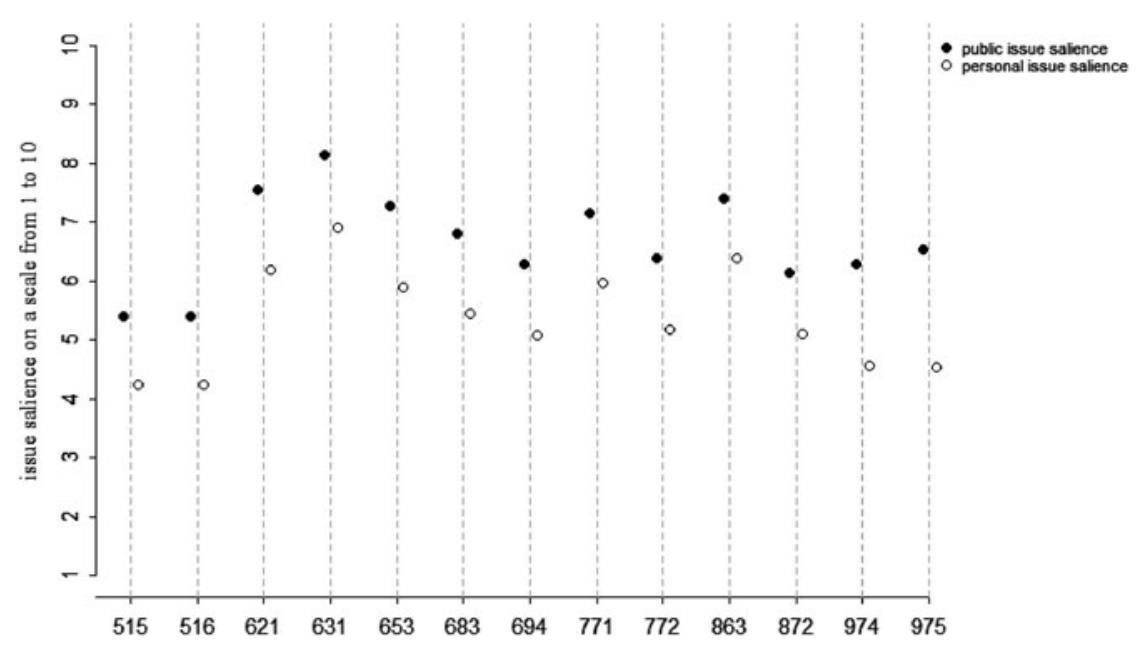

FIgURE 1. Public and personal issue salience of morality issue. Note: The results are based on the following survey question: (1) How salient is this ballot issue for you personally? (2) How salient do you think is this issue for the general public? These questions weren't asked for the first two ballot votes. The numbers on the $x$-axis identify the different ballot issues as depicted in Table 1 .

\section{RELIGION AND MORAL VOTES}

Since moral policies are based on first principles researchers often rely on cultural factors to explain moral policy outcomes (see e.g., Castles 1994; Fink 2008; Minkenberg 2002; Pickel 2001). Decisions on moral issues are made in political conflicts over indivisible values, which, in turn, are often firmly rooted in religious conceptions of right and wrong (Biggers 2011, 4). Since religion is a key determinant of "competing notions of how we should and should not live - the moral order" (Leege et al. 2002, 13), it is not surprising that it is considered one of the most important factors in explaining moral policy outcomes (Fairbanks 1977; Fink 2008; Hutcheson and Taylor 1973; Minkenberg 2002; Morgan and Meier 1980). Fink (2008), for instance, shows that although economic interest plays a decisive role in stem cell research, variations in embryo research laws across Europe can only be explained if religious factors are taken into consideration. A predominant Catholic church and a larger proportion of Catholics within a country lead to more restrictive laws. Minkenberg (2002) arrives at similar conclusions concerning abortion regulations: A strong Catholic 
church leads to more restrictive abortion regulations, whereas Protestants seem to be in general more liberal concerning abortion issues. The study by Morgan and Meier (1980) concentrates on the religious effects on referenda voting in Oklahoma and concludes that religious factors on the countylevel are just as important as economic factors in explaining moral policy outcomes in referenda voting. This is in line with findings by Fairbanks (1977) on state liquor and gambling laws in the United States: Religious forces offer better explanations of the variance across states than economic interests.

Drawing on these insights and with regard to direct democratic decision-making, religion should factor heavily into individuals' vote decisions (liberalizing or restrictive) on moral issues. On a general level an affiliation or self-identification with a particular religious tradition should impact on political behavior because it provides a social context in which individuals can connect their faith to political choices (Green 2010, 24). First, an individual's core values are rooted in a respective religious tradition and these core values are an important source for voting decisions. Second, religious leaders or members of the clergy provide internal cues by emphasizing the importance of these core values and by taking positions on political issues (Djupe and Gilbert 2008). However, these social processes are not limited to the local parish. Individual positions may also be influenced by the prevailing religious norms within the wider community (Kotler-Berkowitz 2001; Lenksi 1961; Traunmüller 2011). And third, political parties, interest groups, and candidates seek support from religious communities by providing them with actionable information. As a result, individual voting behavior may be strongly influenced by general party alignments and the positions political parties take on moral issues. Actual religious participation reinforces all of these three mechanisms, since the most active members will be likely to most strongly adhere to the core values of their religious community and will also be more likely to be exposed to internal cues or external appeals (Djupe and Gilbert 2008; Green 2010; Norris and Inglehart 2004; Verba et al. 1995).

Regarding the traditional confessional cleavage in Switzerland - and therefore the belonging dimension of religion ${ }^{2}$ - we hypothesize that Protestants and Catholics will differ in their voting behavior on moral issues. An influential line of thought stresses the lasting role religious traditions play in forming the cultural and social life in a given nation or region (Fox 2013; Inglehart and Baker 2000; Norris and Inglehart 2004; Toft et al. 2013; Weber [1920] 1988). According to this perspective, 
distinctive worldviews that were historically linked with or that once originated from religious traditions have left deep imprints on contemporary moral beliefs and values. Today, these values are part of the general culture and are shared by most of the citizens in a given context - regardless of whether they actually identify with the religious tradition. For example, the Protestant ethic of hard work and an ascetic life became imprinted in peoples' minds following Calvin's sermon in Geneva, and still has a psychological impact on Protestants, even on those who do not believe in predestination (Geissbühler 1999, 227). Accordingly, we not only expect that citizens differ in their voting decisions on moral issues depending on their individual religious belonging, i.e., whether they are Protestant or Catholic (Hypothesis 1), but also depending on the dominant religious tradition in the regional context within which they are situated (Hypothesis 2). ${ }^{3}$

One fundamental difference between Protestant and Catholic worldviews with far reaching consequences for moral values concerns the role of the individual in its relation to God and the wider community: Whereas Protestants emphasize the individual's relationship with God, Catholics believe that the individual is related to God through the community (Greeley 1989, 485). The opposing positions of the generally more conservative Catholics who support traditional moral issues and the more liberal and flexible attitudes of Protestants are thus deeply rooted in the traditions' respective communalism and individualism (Norris and Inglehart 2004; Scheepers and van der Slik 1998; Scott 1998). This also suggests that the moral positions of the two religious traditions will depend on the specific content of the respective issue: "Protestants will be especially likely to deplore vices which diminish personal integrity, honesty, and sense of duty. Catholics will be especially likely to be offended by actions which seem to violate relationship networks - adultery, prostitution, suicide" (Greely 1989, 487). As a result, we expect that Catholics will in general vote more restrictively on issues such as stem cell research as well as on abortion or homosexuality, but will be more liberal on issues concerning alcohol and drug use or gambling as compared to Protestants who may be inclined toward a rather ascetic and pious lifestyle (Greely 1989; Richard et al. 2000) (Hypothesis 3).

Although religious belonging has long been the primary mode connecting religion and political behavior, scholars in both the United States and Europe argue that differences within religious traditions are becoming more politically relevant than differences among religious traditions (Geissbühler 1999; Green 2010; Voll 1991; Wolf 1996). In other words, 
the old confessional gap of the Protestant/Catholic divide is increasingly replaced by a new religious gap dividing the religious from the secular. Religious behaving is more or less independent of an individual's denomination and reflects true religiosity as well as the actual incorporation of religious beliefs and values (Nicolet and Tresch 2009). It is therefore important to compare individuals who are highly religious to those who are less or not religious. Moreover, the effect from religious belonging on the voting decision may be affected by the actual religious behavior. For instance, a negative effect from Catholic religious belonging should be even stronger for individuals that regularly attend religious service. Concerning the religious behaving dimension we thus hypothesize that, first, religious behavers will vote more restrictively on moral issues (Hypothesis 4). And second, that the effect of religious belonging on the voting decision concerning moral issues will be stronger for individuals that regularly attend religious service (Hypothesis 5).

The juxtaposition of the old confessional and the new religious cleavage already suggests a changing role of individual religiosity on voting behavior over time, but the exact nature of this dynamic is far from clear. There are heated debates concerning the changing role of religion in the public and political sphere. The popular view of secularization predicts that the effect of religious belonging as well as religious behaving will decline over time as the moral authority of the churches weakens and people become more individualized in their preferences and values. Moreover, rapid social changes, urbanization, enhanced political mass participation, and economic prosperity undermine the importance of religion for individuals and modern states (Bruce 2002; 2009; Fox 2013; Norris and Inglehart 2004). Despite this emphasis on the social irrelevance of religion in secularized democracies, the opposite may be just as plausible. In fact, proponents of post-materialism, such as Ronald Inglehart (1977), argue that the shift from materialist politics to more value-based politics actually increases the salience of religiosity for political orientations as well as behaviors and thus renders religion more important. Accordingly, Geser (1997, 3) asserts that "while these developments certainly help to bring attitudinal divergences between religious and non-religious population segments into sharper relief (e.g., in the abortion issue), they may also favor the survival (or even the strengthening) of inter-confessional divergences." In this line, Toft et al. (2011) as well as Fox (2013) argue that the religious divide still persists but has changed from the animosities between different religious groupings to greater conflicts between religious and secular segments of the population. Summarizing these two 
arguments we cannot formulate a clear-cut hypothesis as the effect of religious belonging and behaving on decisions concerning moral issues could both decrease or increase over time (Hypothesis 6).

As already mentioned party politics may further play a crucial role in defining the relationship between individual religiosity and voting decisions on moral issues, since parties seek to mobilize the support of their constituencies, and further provide information as well as political recommendations. In Switzerland, the Christ-Democratic Popular Party (CVP) - which originated from the classical confessional cleavage in Switzerland - may have a strong influence on how Catholics and religious individuals in general vote on moral issues. In this line, we predict that a liberal party parole from the CVP should influence religious belongers and behavers to cast a more liberal vote on moral issues (Hypothesis 7).

\section{DATA AND METHODS}

To test our seven hypotheses we draw on the Vox Analysis, which comprise standardized surveys of 1,000 respondents conducted for each issue of every national public vote in Switzerland since 1977. These Vox surveys were established to receive better insights into individual voting behavior in Swiss initiatives and referenda. Accordingly, they not only ask vote-specific questions (e.g., participation, decision), but also collect information on general socio-economic variables such as sex, age, education, or religious affiliation. Overall we identified 15 moral issue votes for the period between 1992 and 2012, but unfortunately, since one of our main explanatory variables - church attendance - is missing for two referenda, we had to limit our sample to 13 referenda and initiatives. Among them are three concerning questions of genetic engineering, seven concerning issues of drug abuse or gambling (addictive behavior), and three on abortion and homosexuality (sexuality). Individual decisions in these moral referenda are our dependent variable and are coded 1 for a liberal decision and 0 for a restrictive decision on the respective moral issue. ${ }^{4}$ Out of the 13 moral issues on the Swiss national ballot between 1992 and 2012, 11 resulted in a liberal decision.

Our main explanatory variables are an individual's religious affiliation (belonging) and church attendance (behaving), both of which capture the institutional dimension of religion as well as the old and new religious cleavage in Switzerland (Nicolet and Tresch 2009). As we are mainly 
interested in the difference in voting behavior of Catholics and Protestants, we restrict our sample to these two-denominational categories. Forty-three percent of the respondents in our sample identify as Protestant and 42 percent as Catholic. All other confessions as well as the non-religious are not considered in the following analysis. The religious denomination dummy is coded 0 for Protestants and 1 for Catholics. Overall Protestants and Catholics are equally distributed in each of the 13 surveys.

Religious behaving is measured as a respondents' church attendance which ranges from 1 (never) to 5 (once a week) and is treated as continuous. Figure 2 depicts the percentages of weekly (upper graph) and no church attendance (lower graph) for Catholics and Protestants in the 13 moral issue votes in Switzerland. From the upper graph we can conclude that Catholics are more frequent church goers than Protestants, whereas they hardly differ in the category for no church attendance (see lower graph). In sum, there are some minor fluctuations throughout the 13 popular votes, but in general both percentages of weekly and no church attendance are rather stable over the years.

We further consider the percentage of Catholics on the cantonal level as well as the regional mean of church attendance to test the effects of contextual religiosity. Information for the former is taken from official Swiss census data (Eidgenoessische Volkszaehlung 2000); information on cantonal religious behaving was aggregated from the individual level survey data. Following our argumentation from Hypothesis 7 we further include the vote recommendation from the Christ-Democratic Popular Party $(0=$ restrictive, $1=$ liberal $)$ on the referendum level in order to capture a potential political party influence.

Finally, we take into account additional control variables that are said to influence individual political behavior in popular votes. These are age, gender, educational level, and political ideology on the individual level. The prediction is that older, less educated, and ideologically right individuals will generally hold more conservative attitudes leading to a less liberal voting decision (see for example, Milic 2008). Concerning gender we assume that females will generally be more restrictive in their voting pattern, although they are said to be more liberal on issues concerning homosexuality (Olson et al. 2006). As a Swiss specific variable we add a measure for the linguistic region to the models and further control for urbanization as this factor is often said to lead to more liberal values (Inglehart and Baker 2000). All variables except for the dummies are standardized by subtracting the mean and dividing by two standard deviations (Gelman and Hill 2007). 
(a) Weekly church attendance

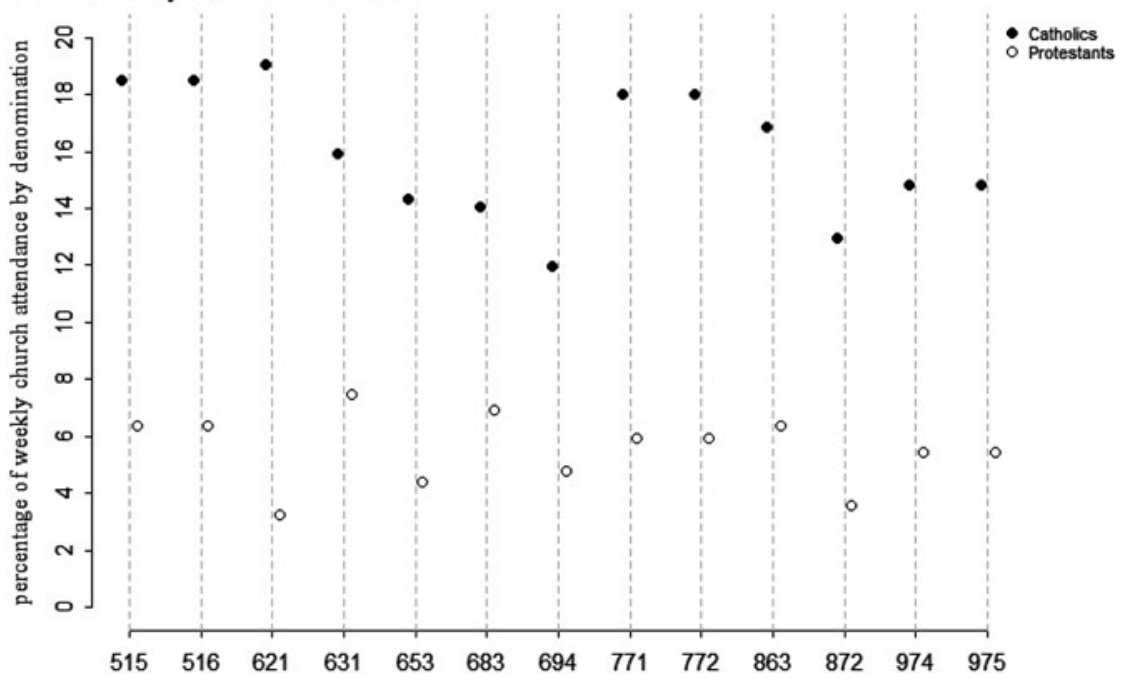

(b) No church attendance

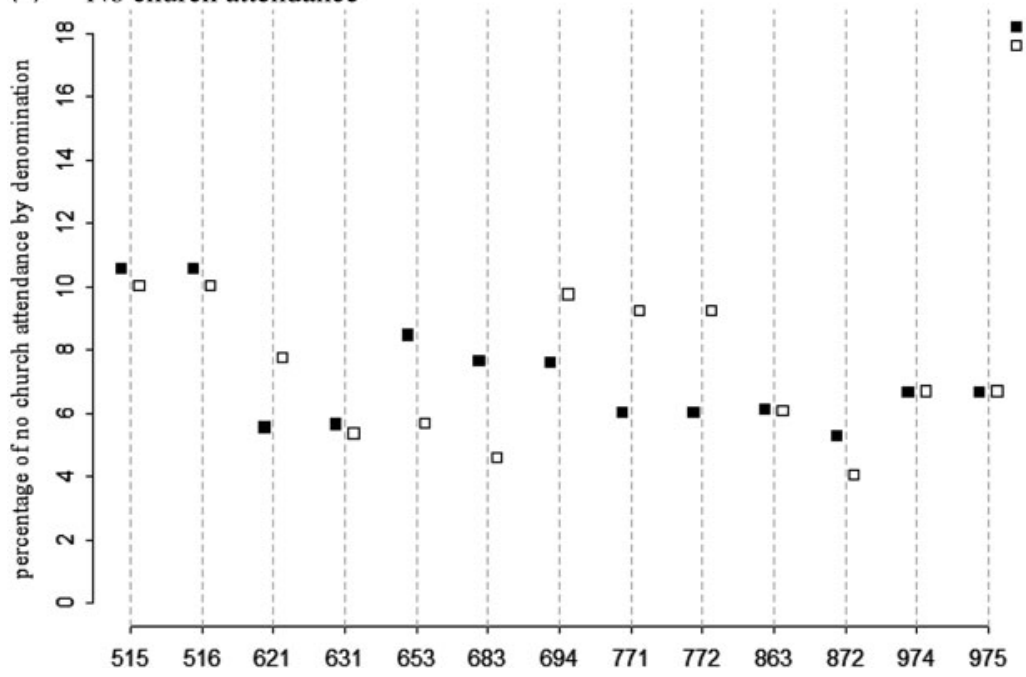

FIGURE 2. Minimum and maximum church attendance by denomination and moral issue vote. Note: The numbers on the $x$-axis identify the different ballot issues as depicted in Table 1.

To test the hypotheses on religion's role in individual voting behavior, we estimate a series of Cross-classified Logistic Multilevel Models where $N=5147$ individual respondents are cross-classified according to two grouping levels: $J=13$ referenda and $K=26$ cantons (Gelman and Hill 
2007). The estimation procedure is based on Maximum Penalized Likelihood, which is equivalent to Bayesian estimation with priori-distribution of the unknown variance component (Chung et al. 2012). We use the blme-package in $R$ for the estimation (Dorie 2011).

\section{RESULTS}

Our results are presented in Tables 2 and 3. To test our hypotheses we proceed as follows: First, we ran a model testing the traditional confessional cleavage between Protestants and Catholics together with the new divide along religious behaving (M1). In the next step, we add the interaction between both of these variables (M2). Model M3 further includes the variables for the religious contexts on the cantonal level, and models M4 and M5 test the cross-level-interactions between individual and cantonal level religiosity allowing a varying slope for individual religiosity. We then turn to the referendum level where models M6 and M7 introduce the time perspective analyzing the potential secularization processes. We accommodate this in the models by letting the slopes of individual religiosity vary over referenda and including a cross-level interaction between individual religiosity and year on the referendum level. As we further predict that Catholics and Protestants will differ in their voting behavior based on the specific moral issue dimension, we then introduce a model testing the cross-level interaction between individual religiosity and the referendum specific moral issue dimensions (M8 and M9). Last, we test whether the vote recommendation by the CVP in a given referendum affects the way individual religiosity is related to vote choice in M10 and M11.

Before turning to the results of primary interest we can quickly summarize the effects of the control variables. Throughout the models as depicted in Tables 2 and 3 we see that younger and higher educated respondents as well as males and persons whose political views tend toward the left will be more likely to vote liberally on moral issues. Living in a more urbanized area adds to this positive effect, whereas language region is unimportant.

Turning to the effects of religion and looking at M1 in Table 2, we find that religious belonging has a negative but not significant impact on a liberal vote decision concerning moral issues. Thus substantively, and contrary to our Hypothesis 1, Protestants and Catholics do not differ in their vote choice regarding moral policy. In contrast to this, the effect of church attendance on liberal vote decisions is highly significant and negative indicating that regular church goers will be more likely to vote restrictively on moral 
Table 2. Regression results from multilevel analysis on the effect from religious belonging and behaving on liberal vote decisions - individual and cantonal influences

\begin{tabular}{|c|c|c|c|c|c|}
\hline & M1 & M2 & M3 & M4 & M5 \\
\hline \multicolumn{6}{|l|}{ Individual level } \\
\hline religious belonging & -0.10 & -0.11 & -0.11 & -0.09 & -0.08 \\
\hline$(1=$ Catholic $)$ & $(0.07)$ & $(0.07)$ & $(0.08)$ & $(0.09)$ & $(0.08)$ \\
\hline \multirow[t]{2}{*}{ religious behaving } & $-0.70 * *$ & $-0.81 * *$ & $-0.66 * *$ & $-0.69 * *$ & $-0.71 * *$ \\
\hline & $(0.07)$ & $(0.10)$ & $(0.10)$ & $(0.07)$ & $(0.10)$ \\
\hline belonging*behaving & & $\begin{array}{c}0.18 \\
(0.13)\end{array}$ & & & \\
\hline \multirow[t]{2}{*}{ female } & $-0.15 * *$ & $-0.16^{* *}$ & $-0.14 * *$ & $-0.15^{* *}$ & $-0.14 * *$ \\
\hline & $(0.07)$ & $(0.07)$ & $(0.07)$ & $(0.07)$ & $(0.07)$ \\
\hline \multirow[t]{2}{*}{ age } & $-0.30 * *$ & $-0.31 * *$ & $-0.30 * *$ & $-0.30 * *$ & $-0.28 * *$ \\
\hline & $(0.07)$ & $(0.07)$ & $(0.07)$ & $(0.07)$ & $(0.07)$ \\
\hline \multirow[t]{2}{*}{ education } & $0.08 * *$ & $0.08 * *$ & $0.09 * *$ & $0.09 * *$ & $0.10 * *$ \\
\hline & $(0.02)$ & $(0.02)$ & $(0.02)$ & $(0.02)$ & $(0.02)$ \\
\hline \multirow[t]{2}{*}{ political ideology } & $-0.17 * *$ & $-0.18 * *$ & $-0.16^{* *}$ & $-0.17 * *$ & -0.16 \\
\hline & $(0.07)$ & $(0.07)$ & $(0.07)$ & $(0.07)$ & $(0.15)$ \\
\hline \multicolumn{6}{|l|}{ Cantonal level } \\
\hline$\%$ Catholics & & & $\begin{array}{c}0.12 \\
(0.15)\end{array}$ & $\begin{array}{c}0.34 \\
(0.20)\end{array}$ & $\begin{array}{c}0.07 \\
(0.16)\end{array}$ \\
\hline \multirow[t]{2}{*}{ mean attendance } & & & -0.20 & -0.21 & -0.16 \\
\hline & & & $(0.14)$ & $(0.20)$ & $(0.15)$ \\
\hline belonging* \% Catholics & & & & $\begin{array}{c}-0.36 \\
(0.26)\end{array}$ & \\
\hline belonging*mean & & & & 0.10 & \\
\hline attendance & & & & $(0.25)$ & \\
\hline behaving* \% Catholics & & & & & $\begin{array}{c}0.17 \\
(0.28)\end{array}$ \\
\hline \multicolumn{2}{|l|}{ behaving*mean } & & & & 0.03 \\
\hline \multirow{2}{*}{$\begin{array}{l}\text { attendance } \\
\text { urban region }\end{array}$} & & & & & $(0.25)$ \\
\hline & $-0.16^{* *}$ & $-0.16^{* *}$ & $-0.16^{* *}$ & $-0.17 * *$ & $-0.15^{* *}$ \\
\hline \multirow{2}{*}{ linguistic region } & $(0.07)$ & $(0.07)$ & $(0.07)$ & $(0.07)$ & $(0.07)$ \\
\hline & 0.15 & 0.15 & 0.16 & 0.16 & 0.18 \\
\hline & $(0.10)$ & $(0.10)$ & $(0.11)$ & $(0.11)$ & $(0.11)$ \\
\hline \multirow[t]{2}{*}{ Intercept } & 0.83 & 0.82 & 0.80 & 0.81 & 0.77 \\
\hline & $(0.29)$ & $(0.29)$ & $(0.31)$ & $(0.31)$ & $(0.32)$ \\
\hline \multicolumn{6}{|l|}{ Variance components } \\
\hline intercept SD cantons & 0.15 & 0.15 & 0.16 & 0.16 & 0.15 \\
\hline slope SD belonging & & & & 0.16 & \\
\hline slope SD behaving & & & & & 0.26 \\
\hline intercept SD referenda & 0.86 & 0.86 & 0.89 & 1.00 & 0.74 \\
\hline$N$ Individuals & 5147 & 5147 & 5147 & 5147 & 5147 \\
\hline$J$ Referenda & 13 & 13 & 13 & 13 & 13 \\
\hline$K$ Cantons & 26 & 26 & 26 & 26 & 26 \\
\hline
\end{tabular}

Note: Results from cross-classified logistic multilevel models; unstandardized coefficients (logits) presented; standard errors in parentheses; ${ }^{*} p<0.05$, ${ }^{* *} p<0.01$; correlations between varying intercepts and varying slopes not shown. 
Table 3. Regression results from multilevel analysis on the effect from religious belonging and behaving on liberal vote decisions - influences on referendum-level

\begin{tabular}{|c|c|c|c|c|c|c|}
\hline & M6 & M7 & M8 & M9 & M10 & M11 \\
\hline \multicolumn{7}{|l|}{ Individual level } \\
\hline religious belonging & 0.18 & -0.07 & 0.04 & -0.06 & $-0.35^{*}$ & -0.05 \\
\hline (1 = Catholic) & $(0.15)$ & $(0.07)$ & $(0.19)$ & $(0.07)$ & $(0.18)$ & $(0.07)$ \\
\hline \multirow[t]{2}{*}{ religious behaving } & $-0.69 * *$ & -0.42 & $-0.71 * *$ & -0.42 & $-0.68 * *$ & $-1.33 * *$ \\
\hline & $(0.07)$ & $(0.29)$ & $(0.07)$ & $(0.25)$ & $(0.07)$ & $(0.31)$ \\
\hline \multirow[t]{2}{*}{ female } & $-0.14 * *$ & $-0.14 * *$ & $-0.16^{* *}$ & $-0.14 * *$ & $-0.17 * *$ & -0.13 \\
\hline & $(0.07)$ & $(0.07)$ & $(0.07)$ & $(0.07)$ & $(0.07)$ & $(0.07)$ \\
\hline \multirow[t]{2}{*}{ age } & $-0.31 * *$ & $-0.30 * *$ & $-0.31 * *$ & $-0.28 * *$ & $-0.32 * *$ & $-0.28 * *$ \\
\hline & $(0.07)$ & $(0.07)$ & $(0.07)$ & $(0.07)$ & $(0.07)$ & $(0.07)$ \\
\hline \multirow[t]{2}{*}{ education } & $0.09 * *$ & $0.09 * *$ & $0.09 * *$ & $0.09 * *$ & $0.09 * *$ & $0.08 * *$ \\
\hline & $(0.02)$ & $(0.02)$ & $(0.02)$ & $(0.02)$ & $(0.02)$ & $(0.02)$ \\
\hline \multirow[t]{2}{*}{ political ideology } & $-0.17 * *$ & $-0.16^{* *}$ & $-0.17 * *$ & $-0.15^{* *}$ & $-0.15 * *$ & $-0.14 * *$ \\
\hline & $(0.07)$ & $(0.07)$ & $(0.07)$ & $(0.07)$ & $(0.07)$ & $(0.07)$ \\
\hline \multicolumn{7}{|l|}{ Cantonal level } \\
\hline urban region & $\begin{array}{c}-0.13 * * \\
(0.07)\end{array}$ & $\begin{array}{c}-0.14 * * \\
(0.07)\end{array}$ & $\begin{array}{c}-0.15 * * \\
(0.07)\end{array}$ & $\begin{array}{c}-0.14 * * \\
(0.07)\end{array}$ & $\begin{array}{c}-0.12 \\
(0.07)\end{array}$ & $\begin{array}{c}-0.12 \\
(0.07)\end{array}$ \\
\hline linguistic region & $\begin{array}{c}0.15 \\
(0.11)\end{array}$ & $\begin{array}{c}0.17 \\
(0.11)\end{array}$ & $\begin{array}{c}0.15 \\
(0.10)\end{array}$ & $\begin{array}{c}0.19 \\
(0.11)\end{array}$ & $\begin{array}{c}0.17 \\
(0.11)\end{array}$ & $\begin{array}{c}0.17 \\
(0.11)\end{array}$ \\
\hline \multicolumn{7}{|l|}{ Referendum level } \\
\hline year & $\begin{array}{c}-0.01 \\
(0.05)\end{array}$ & $\begin{array}{c}-0.03 \\
(0.06)\end{array}$ & & & & \\
\hline belonging*year & $\begin{array}{c}-0.04 * * \\
(0.02)\end{array}$ & & & & & \\
\hline behaving*year & & $\begin{array}{l}-0.05 \\
(0.03)\end{array}$ & & & & \\
\hline \multicolumn{7}{|l|}{ issue dimension $^{\mathrm{a}}$} \\
\hline addictive behavior & & & $\begin{array}{l}-0.67 \\
(0.52)\end{array}$ & $\begin{array}{c}-0.27 \\
(0.66)\end{array}$ & & \\
\hline sexuality & & & $\begin{array}{c}0.27 \\
(0.62)\end{array}$ & $\begin{array}{c}0.70 \\
(0.79)\end{array}$ & & \\
\hline belonging*add.behav. & & & $\begin{array}{c}-0.09 \\
(0.23)\end{array}$ & & & \\
\hline belonging*sexuality & & & $\begin{array}{c}-0.35 \\
(0.27)\end{array}$ & & & \\
\hline behaving*add.behav. & & & & $\begin{array}{c}-0.17 \\
(0.30)\end{array}$ & & \\
\hline behaving*sexuality & & & & $\begin{array}{c}-1.11^{* *} \\
(0.36)\end{array}$ & & \\
\hline CVP recommendation & & & & & $\begin{array}{l}1.37 * * \\
(0.43)\end{array}$ & $\begin{array}{l}1.40 * * \\
(0.51)\end{array}$ \\
\hline belonging $* \mathrm{CVP}$ recom. & & & & & $\begin{array}{c}0.33 \\
(0.20)\end{array}$ & \\
\hline behaving*CVP recom. & & & & & & $\begin{array}{l}0.70 * * \\
(0.35)\end{array}$ \\
\hline
\end{tabular}


Table 3. Continued

\begin{tabular}{lcccccc}
\hline & M6 & M7 & M8 & M9 & M10 & M11 \\
\hline Intercept & 0.83 & 1.05 & 1.12 & 0.76 & -0.30 & -0.41 \\
& $(0.50)$ & $(0.55)$ & $(0.47)$ & $(0.58)$ & $(0.41)$ & $(0.48)$ \\
Variance components & & & & & & \\
$\begin{array}{l}\text { Intercept SD cantons } \\
\text { Intercept SD }\end{array}$ & 0.16 & 0.16 & & 0.17 & 0.16 & 0.19 \\
$\begin{array}{l}\text { Referenda } \\
\text { slope SD belonging }\end{array}$ & 0.89 & 1.00 & & 0.95 & 0.63 & 0.76 \\
$\begin{array}{l}\text { slope SD behaving } \\
N \text { Individuals }\end{array}$ & 0.15 & & 0.81 & & & \\
$J$ Referenda & 5147 & 5147 & 5147 & 5147 & 5147 & 5147 \\
$K$ Cantons & 13 & 13 & 13 & 13 & 13 & 13 \\
\hline
\end{tabular}

Note: Results from cross-classified logistic multilevel models; unstandardized coefficients (logits) presented; standard errors in parentheses; ${ }^{*} p<0.05$, $* * p<0.01$; correlations between varying

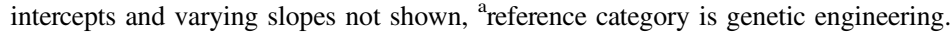

issues. This result is in line with our prediction from Hypothesis 4. Based on these results one may further assume that only religious adherents, which regularly attend religious services will differ in their voting behavior on moral issues. Turning to the results of M2 which test this assumption as stated in Hypothesis 5 we see, however, that this prediction is not confirmed as the interaction term between religious belonging and behaving is far from significant. The effect from religious belonging on a liberal vote decision, thus, is not conditional on the level of an individual's actual religious behaving. The new religious cleavage between the religious and the secular is clearly more relevant when it comes to referenda voting on moral issues than the traditional confessional cleavage between Protestants and Catholics. Whatever value differences may have existed between the two confessions in the past, they are not visible any more today. This also holds when we look at religion as explanatory factors on the cantonal level. Here, neither the regional share of Catholics nor the average church attendance rates in the cantons affect the probability of casting a liberal vote on moral issues (M3). Religious contexts also do not moderate the effects of individual religious belonging or behaving on voting behavior concerning moral issues (M4 and M5).

Table 3 introduces explanatory factors on the referendum level. M6 and M7 test the assumptions of the (non-)secularization theory (Hypothesis 6). We estimated two separate models for the time dependency of the effects of religious belonging and religious behaving, respectively, by adding interactions with years to the equations. However, we only find a significant interaction between religious belonging and year of the referendum. 
Relative to Protestants, Catholics tend to vote slightly more restrictively over the years. Whereas the two denominations did not differ in their voting behavior in 1993, Catholics voted more restrictive than Protestants in referenda from 2003 onwards (see Figure 3 for an illustration). The effect of individual church attendance in turn is not moderated by time but stays stable over the period of investigation. Both results run counter to the idea of a decreasing public relevance of religion as put forward by classical secularization theory. That the increase in restrictive voting of Catholics cannot be reduced to specific issues decided at the ballot becomes apparent when we look at whether Protestants and
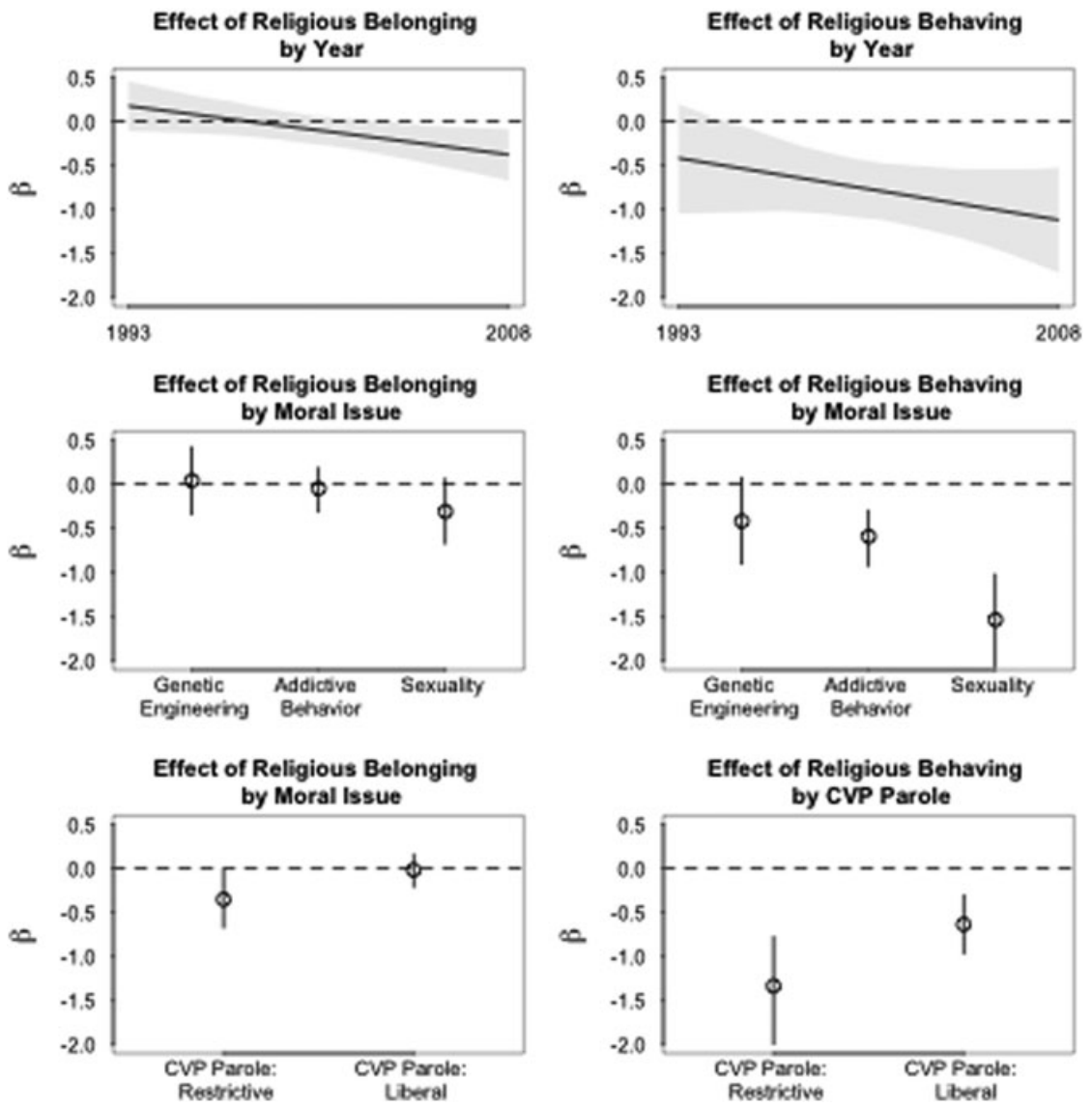

FIGURE 3. Cross-level interactions between individual religiosity and referendum characteristics. Note: Based on the results reported in Table 3; Conditional effects (logits) and $95 \%$ confidence intervals shown. 
Catholics differ in their voting behavior depending on the content of the moral issue in question (M8). This is not the case as the non-significant findings for the interactions between issue dimensions and individual religious denomination suggest. While the graph in Figure 3 shows that Catholics tend to vote more restrictively on issues on sexual morality the confidence interval includes zero. Instead, and turning to the results of M9 which includes the interaction between religious behaving and the moral issue dimensions, we find that regular churchgoers will vote markedly less liberal on policies concerned with questions of abortion and homosexuality than on other moral policy issues. Indeed, differences in the attitudes toward abortion and homosexuality seem to lie at the very heart of the moral cleavage between religious and secular segments of the Swiss population.

Finally, the results of M10 and M11 show that part of the connection between individual religiosity and voting behavior depends on the mobilization by political parties. Regardless of respondents' denomination, the nature of the CVP's vote recommendation has a strong effect on their vote decision: if the CVP recommends a liberal vote decision both Protestants and Catholics are more likely to cast a liberal vote on the moral issue. Moreover, as the significant interaction between vote recommendation and religious behaving shows, a liberal vote recommendation from the CVP considerably decreases the general restrictive vote intention of regular churchgoers. This result, which is in line with our Hypothesis 7, clearly demonstrates an important political mechanism of how individual religiosity translates into political decisions at the ballot.

\section{CONCLUSION}

The aim of our study was to investigate the religious factor in referenda voting on moral issues. We went beyond the existing research literature on direct democracy and moral politics by shifting our focus away from the policy outcomes of referenda and instead turning to the input side of direct democracy: how does religion influence citizens' vote decisions in referenda and popular initiatives regarding moral issues? Although 11 out of the 13 moral referenda in Switzerland since 1992 resulted in a liberal decision, suggesting growing liberal tendencies overall, religion turns out to be a crucial factor in explaining differences in individual voting behavior.

In particular, our results show that religious behaving, and not nominal religious belonging, plays a crucial role in decision making on issues 
concerning abortion, genetic engineering, drug abuse gambling, and homosexuality. Actual religious practice in terms of church attendance leads to more restrictive votes. This effect has been very stable over the years and gives evidence for the continuing role of religion in explaining moral issue votes. However, Protestants and Catholics do not differ in their voting patterns on moral issues, even when taking into account the religious behaving dimension. In addition, the voting patterns of Catholics and Protestants do not differ across specific moral issues.

This result supports the general idea that traditional confessional cleavages between members of different denominations are increasingly being replaced by a new religious cleavage that divides the religious from the secular and thus adds to the current debate on the stability and change of religious cleavage voting in Europe (e.g., Ackermann and Traunmüller 2014; Brooks et al. 2006; Elff 2007; Essmer and Pettersson 2010; Knutsen 2004; Minkenberg 2010). As our findings on the moderating role of the CVP's vote recommendation for the vote choices of regular churchgoers show, this "new" religious cleavage is characterized by clear party alignments and political loyalties that extend from electoral to direct democratic voting behavior.

While we took a slightly different analytic perspective due to the unique availability of referenda specific surveys in Switzerland, our study also lends support and generalizes some of the previous findings drawn from American research on moral politics, direct democracies, and the role of religion (Campbell 2007; Donovan et al. 2008; Fairbanks 1977; Feddersen et al. 2009; Fiorina 2005; Green 2010; Morgan and Meier 1980; Olson et al. 2006; Roh and Haider-Markel 2003). Heated political debates pitting religious and secular segments of the population against one another on moral issues such as abortion or gay rights are by no means unique to the United States. In fact, questions of abortion rights and the recognition of homosexuality are also the core issues that divide the religious and non-religious in the Swiss case. Since the question of opening up morality issues to the ballot box arises in more and more democratic countries, future research should undertake similar analyses in countries such as Italy, Ireland, Portugal, or New Zealand to increase our understanding of how religion and politics define how we should and should not live.

\section{NOTES}

1. In our study, we will stick to the most prominent moral issues stated in literature (especially Knill 2013; Mooney 2001; Studlar 2001) as they occur mostly in public referenda. Moreover, the Catholic as 
well as the (Swiss) Protestant church hold unambiguous restrictive opinions on these issues, which makes them rather clear-cut on this dimension.

2. Individual religiosity is usually conceptualized as a multi-dimensional construct compromising the three B's of religiosity: belonging, behaving, and believing (e.g., Jelen 2009; McTague and Layman 2009; Nicolet and Tresch 2009; Putnam and Campbell 2012; Stark and Glock 1968). Throughout social science this construct is better known as religious commitment (Stark and Glock 1968), which has long been used to capture the effects from individual aspects of religion on social and political behavior (Jelen 2009; McTague and Layman 2009). The three aspects of religiosity, belonging, behaving, and believing, are thereby not country specific, although this concept has been mainly used to analyze the effects of religious commitment in the American context (Jelen 2009; Layman 2001; McTague and Layman 2009; Olson et al. 2006; Stark and Glock 1968). This multi-dimensional construct of religious membership applies to all countries where religion is present, and thus should be appropriate to conceptualize Swiss religiosity as well. Whereas belonging refers to a more or less formal affiliation or self-identification with a particular religious tradition, behaving refers to the actual practice of one's faith, most prominently church attendance. Believing complements the concept of individual religiosity and refers to the particular religious contents and ideas an individual holds. We only focus on religiosity in terms of belonging and behaving, since these are the only aspects captured in our surveys. This distinction however applies very well to the traditional confessional cleavage between Catholics and Protestants and the more recent religious cleavage between the secular and the religious.

3. Of course, Protestants do not constitute a homogeneous group. There are numerous heterogeneous branches, especially in the United States context (Putnam and Campbell 2012). In Europe, Protestants are divided historically in Reformed (Calvinists) and Lutherans (Manow 2002). In Switzerland, however, the vast majority of Protestants are Reformed based on the strong historic connection to Calvin and Zwingli (Geissbuehler 1999).

4. Some of the values for votes had to be rotated so that a "yes vote" equals a liberal decision and a "no vote" equals a restrictive decision.

\section{REFERENCES}

Ackermann, Kathrin, and Richard Traunmüller. 2014. "Jenseits von Schwerkraft und Höllenfeuer. Nicht-lineare Kontexteffekte auf den Zusammenhang von religiöser Gruppenzugehörigkeit und individuellem Wahlverhalten bei fünf Bundestagswahlen." Politische Vierteljahresschrift 55:33-66.

Biggers, Daniel. 2011. "When Ballot Issues Matter: Social Issue Ballot Measures and Their Impact on Turnout." Political Behavior 33:3-25.

Brooks, Clem, Paul Nieuwbeerta and Jeff Manza. 2006. "Cleavage-Based Voting Behavior in Cross-National Perspective: Evidence From Six Postwar Democracies." Social Science Research 35:88-128.

Bruce, Steve. 2002. God is Dead. Secularization in the West. Malden: Blackwell Publishing. Bruce, Steve. 2009. "Secularization and Politics." In Routledge Handbook of Religion and Politics, ed. Haynes, Jeffrey. New York, NY: Routledge, 145-158.

Camobreco, John F., and Michelle A. Barnello. 2008. "Democratic Responsiveness and Policy Shock: The Case of State Abortion Policy." State Politics \& Policy Quarterly 8:48-65.

Campbell, David E. ed. 2007. A Matter of Faith. Religion in the 2004 Presidential Election. Washington, DC: Brookings Institution Press.

Castles, Francis G. 1994. "On Religion And Public Policy: Does Catholicism Make A Difference?" European Journal of Political Research 25:19-40.

Chung, Yeojin, Sophia Rabe-Hesketh, Vincent Dorie, Andrew Gelman, Andrew, and Jingchen Liand 2012. "A Non-Degenerate Estimator for Variance Parameters in Multilevel Models via Penalized Likelihood Estimation." Psychometrika (forthcoming).

Djupe, Paul A., and Christopher P. Gilbert. 2008. The Political Influence of Churches. Cambridge: Cambridge University Press. 
Donovan, Todd, Caroline J. Tolbert, and Danile Smith. 2008. "Priming Presidential Votes by Direct Democracy." The Journal of Politics 70:1217-1231.

Dorie, Vincent. 2011. Bayesian Linear Mixed-Effects Models. R package version 0.01-4.

Elff, Martin. 2007. "Social Structure and Electoral Behavior in Comparative Perspective: The Decline of Social Cleavages in Western Europe Revisited." Perspectives on Politics 5:277-294.

Engeli, Isabelle. 2009. "The Challenges of Abortion and Assisted Reproductive Technologies Policies in Europe." Comparative European Politics 7:56-74.

Engeli, Isabelle, and Frédéric Varone. 2011. "Governing Morality Issues through Procedural Policies." Swiss Political Science Review 17:239-258.

Fabrizio, Paul J. 2001. "Evolving into Morality Politics: U.S. Catholic Bishops' Statements on U.S. Politics from 1972 to the Present." In The Public Clash of Private Values, ed. Mooney, C. Z. New York, NY: Chatham House. 73-90.

Fairbanks, David. 1977. "Religious Forces and 'Morality' Policies in the American States." The Western Political Quarterly 30:411-417.

Feddersen, Timothy, Sean Gailmard, and Alvaro Sandroni. 2009. "Moral Bias in Large Elections: Theory and Empirical Evidence." American Political Science Review 103:175-192.

Fink, Simon. 2008. "Politics as Usual or Bringing Religion Back In?" Comparative Political Studies 41:1631-1656.

Fiorina, Morris P. 2005. Culture War? The Myth of a Polarized America. New York, NY: Longman.

Flanagan, Scott C., and Aie-Rie Lee. 2003. "The New Politics, Culture Wars, and the Authoritarian-Libertarian Value Change in Advanced Industrial Democracies." Comparative Political Studies 36:235-270.

Fox, Jonathan. 2013. "Is it really God's Century? An Evaluation of Religious Support and Discrimination from 1990 to 2008." Politics and Religion 7:4-27.

Geissbühler, Simon. 1999. "Are Catholics Still Different? Catholicism, Political Attitudes and Party Attachments in Switzerland, 1970-95." West European Politics 22:223-240.

Gelman, Andrew and Jennifer Hill. 2007. Data Analysis Using Regression and Multilevel/ Hierarchical Models. Cambridge: Cambridge University Press.

Geser, Hans. 1997. "The Persistence of Confessional Political Culture in Switzerland: Some Puzzling Empirical Evidence from Local Parties." Swiss Political Science Review 3:1-29.

Greeley, Andrew. 1989. "Protestant and Catholic: Is the analogical imagination extinct?" American Sociological Review 54:485-502.

Green, John C. 2010. The Faith Factor. How Religion Influences American Elections. Washington, DC: Potomac Books.

Grummel, John A. 2008. "Morality Politics, Direct Democracy, and Turnout." State Politics \& Policy Quarterly 8:282-292.

Haider-Markel, Donald P. 2001. "Morality in Congress? Legislative Voting on Gay Issues." In The Public Clash of Private Values, ed. Mooney, C. Z. New York, NY: Chatham House, 115-129.

Hunter, James D. 1991. Culture Wars. The Struggle to Define America. New York, NY: Basic Books.

Hutcheson, John D., Jr., and George A. Taylor. 1973. "Religious Variables, Political System Characteristics, and Policy Outputs in the American States." American Journal of Political Science 17:414-421.

Hutson, James. 1991. The Sister Republics, Switzerland and the United States from 1776 to the Present. East Lansing, MI: University of Michigan. 
Inglehart, Ronald. 1977. The Silent Revolution: Changing Values and Political Styles among Western Publics. Princeton, NJ: Princeton University Press.

Inglehart, Ronald, and William E. Baker. 2000. "Modernization, Cultural Change, and the Persistence of Traditional Values." American Sociological Review 65:19-51.

Jelen, Ted G. 2009. "Religion and American Public Opinion: Social Issues." In The Oxford Handbook of Religion and American Politics, eds. Smidt, Corwin E., Lamyn A. Kellstedt, and James L. Guth. Oxford: Oxford University Press, 217-242.

Kirchner, Antje, Markus Freitag, and Carolin Rapp. 2011. "Crafting Tolerance: The Role of Political Institutions in a Comparative Perspective." European Political Science Review 3:201-227.

Knill, Christoph. 2013. "The Study of Morality Policy: Analytical Implications from a Public Policy Perspective." Journal of European Public Policy 20:309-317.

Knutsen, Oddbjorn. 2004. "Religious Denomination and Party Choice in Western Europe: A Comparative Longitudinal Study from Eight Countries, 1970-97." International Political Science Review 25:97-128.

Kotler-Berkowitz, Lawrence A. 2001. "Religion and Voting Behaviour in Great Britain: A Reassessment." British Journal of Political Science 31:523-554.

Kriesi, Hanspeter, and Alexander H. Trechsel. 2008. The Politics of Switzerland: Continuity and Change in a Consensus Democracy. Cambridge: Cambridge University Press.

Lachat, Romain. 2012. "The religious cleavage in Switzerland, 1971-2007." Paper prepared for the Conference "Religiosity, Ideology, and Voting in Europe". Madrid, February 1-3.

Layman, Geoffrey C. 2001. The Great Divide: Religious and Cultural Conflicts in American Party Politics. New York, NY: Columbia University Press.

Layman, Geoffrey C., and John C. Green. 2005. "Wars and Rumors of War: The Contexts of Cultural Conflict in American Political Behavior." British Journal of Political Science 36:61-89.

Leege, David C., Kenneth D. Wald, Brian S. Krueger, and Paul D. Mueller. 2002. The Politics of Cultural Differences. Social Change and Voter Mobilization Strategies in the Post New Deal Period. Princeton, NJ: Princeton University Press.

Lenski, Gerhard. 1961. The Religious Factor: A Sociological Study of Religion's Impact on Politics, Economics, and Family Life. Garden City, NY: Doubleday.

Lijphart, Arend. 1979. "Religious vs. Linguistic vs. Class Voting: The "Crucial Experiment' of Comparing Belgium, Canada, South Africa and Switzerland." American Political Science Review 73:442-458.

Linder, Wolf. 2010. Swiss Democracy. Possible Solutions to Conflict in Multicultural Societies. New York, NY: Palgrave Macmillan.

Manow, Philip. 2002. "The Good, the Bad, and the Ugly." KZfSS Kölner Zeitschrift für Soziologie und Sozialpsychologie 54:203-225.

McTague, John Michael, and Geoffrey C. Layman. 2009. "Religion, Parties, and Voting Behavior: A Political Explanation of Religious Influence." In The Oxford Handbook of Religion and American Politics, eds. Smidt, Corwin E., Lamyn A. Kellstedt, and James L. Guth. Oxford: Oxford University Press, 330-370.

Meier, Kenneth J. 1994. The Politics of Sin. Drugs, Alcohol, and Public Policy. In Bureaucracies, Public Administration, and Public Policy, ed. Meier, Kenneth J. Armonk: M. E. Sharpe.

Milic, Thomas. 2008. Ideologie und Stimmverhalten. Zürich: Ruegger.

Minkenberg, Michael. 2002. "Religion and Public Policy. Institutional, Cultural, and Political Impact on the Shaping of Abortion Policies in Western Democracies." Comparative Political Studies 35:221-247.

Minkenberg, Michael. 2010. "Party Politics, Religion and Elections in Western Democracies." Comparative European Politics 8:385-414. 
Mooney, Christopher Z. 2001. "The Public Clash of Private Values." In The Public Clash of Private Values, ed. Mooney, C. Z. New York, NY: Chatham House, 3-18.

Mooney, Christopher Z., and Mei-Hsien Lee. 2000. "The Influence of Values on Consensus and Contentious Morality Policy: U.S. Death Penalty Reform, 1956-82." The Journal of Politics 62:223-239.

Mooney, Christopher Z., and Richard G. Schuldt. 2008. "Does Morality Policy Exist? Testing a Basic Assumption.” Policy Studies Journal 36:199-218.

Morgan, David, and Kenneth Meier. 1980. "Politics and Morality: The Effect of Religion on Referenda Voting." Social Science Quarterly 61:144-148.

Nicolet, Sarah, and Anke Tresch. 2009. "Changing Religiosity, Changing Politics? The Influence of "Belonging" and "Believing" on Political Attitudes in Switzerland." Politics and Religion 2:76-99.

Norris, Pippa, and Inglehart, Ronald. 2004. Sacred and Secular. Religion and Politics Worldwide. Cambridge: Cambridge University Press.

Olson, Laura R., Wendy Cadge, and James T. Harrison. 2006. "Religion and Public Opinion about Same-Sex Marriage.” Social Science Quarterly 87:340-360.

Pickel, Gert 2001. Moralische Vorstellungen und ihre religiöse Fundierung im europäischen Vergleich. In Religion und Moral. Entkoppelt oder Verknüpft? (English translation here please), eds. Pickel, G., and M. Krüggeler. Opladen: Leske + Budrich, 105-134.

Putnam, Robert D., and David E. Campbell. 2012. American Grace. How Religion Divides and Unites Us. New York, NY: Simon and Schuster.

Richard, Alan J., David C. Bell, and Jerry W. Carlson. 2000. "Individual Religiosity, Moral Community, and Drug User Treatment." Journal for the Scientific Study of Religion 39:240-246.

Roh, Jongho, and Donald P. Haider-Markel. 2003. "All Politics are Note Local: National Forces in State Abortion Initiatives." Social Science Quarterly 84:15-31.

Scheepers, Per, and van der Slik, Frans. 1998. "Religion and Attitudes on Moral Issues: Effects of Individual, Spouse and Parental Characteristics." Journal for the Scientific Study of Religion 37:678-691.

Scott, Jaqueline. 1998. "Generational Changes in Attitudes to Abortion: A Cross-National Comparison.” European Sociological Review 14:177-190.

Schiffino, Nathalie, Celina Ramjoué, and Frédéric Varone. 2009. "Biomedical Policies in Belgium and Italy: From Regulatory Reluctance to Policy Changes." West European Politics 32:559-585.

Smith, M. A. 2001. "The Contingent Effects of Ballot Initiatives and Candidate Races on Turnout." American Journal of Political Science 45:700-706.

Stark, Rodney, and Charles Y. Glock. 1968. American Piety: The Nature of Religious Commitment. Berkeley, CA: University of California Press.

Studlar, Donley T. 2001. "What Constitutes Morality Policy? A Cross National Analysis." In The Public Clash of Private Values, ed. Mooney, C. Z. New York, NY: Chatham House, 37-51.

Studlar, Donley T., Alessandro Cagossi, and Robert D. Duval. 2013. "Is Morality Policy Different? Institutional Explanations for Post-War Western Europe." Journal of European Public Policy 20:353-371.

Toft, Monica Duffy, Daniel Philpott, and Timothy Samuel Shah. 2011. God's Century. Resurgent Religion and Global Politics. New York, NY: Norton and Company. 
Tolbert, Caroline J., John A. Grummel, and Daniel A. Smith. 2001. "The Effects of Ballot Initiatives on Voter Turnout in the American states." American Politics Research 29:625-648.

Tolbert, Caroline J., and Daniel A. Smith. 2005. "The Educative Effects of Ballot Initiatives on Voter Turnout." American Politics Research 33:283-309.

Traunmüller, Richard. 2011. "Moral Communities? Religion as a Source of Social Trust in a Multilevel Analysis of 97 German Regions." European Sociological Review 27:346-363.

Verba, Sidney, Kay L. Schlozman, and Henry Brady. 1995. Voice and Equality: Civic Voluntarism in American Politics. Cambridge, MA: Harvard University Press.

Voll, Peter. 1991. "Konfession und Politik in der Schweiz (English translation here please)." Schweizerissche Zeitschrift für Soziologie (English translation here please) 17:375-406.

Weber, Max. [1920] 1988. Gesammelte Aufsätze zur Religionssoziologie I. Tübingen: Mohr Siebeck.

Wolf, Christof. 1996. "Konfessionelle versus religiöse Konfliktlinie in der deutschen Wählerschaft." Politische Vierteljahresschrift (English translation here please) 37:713-734.

\section{APPENDIX}

Table A1. Variable Description

\begin{tabular}{|c|c|}
\hline Variable & Operationalization and source \\
\hline \multicolumn{2}{|l|}{ Individual level } \\
\hline Vote decision & $\begin{array}{l}\text { Respondent's vote decision on the respective moral issue; } 1=\text { liberal } \\
\text { vote, } 0=\text { restrictive vote (Source: Vox-Data) }\end{array}$ \\
\hline Religious belonging & $\begin{array}{l}\text { Respondent's religious affiliation; } 0=\text { Protestant, } 1=\text { Catholic } \\
\text { (Source: Vox-Data) }\end{array}$ \\
\hline Religious behaving & $\begin{array}{l}\text { Regularity of church attendance ranging from } 1=\text { "once a week" to } \\
5=\text { "never" (Source: Vox-Data) }\end{array}$ \\
\hline Age & Age measured in years (Source: Vox-Data) \\
\hline Sex & $0=$ male, $1=$ female $($ Source: Vox-Data $)$ \\
\hline Education & $\begin{array}{l}\text { Respondent's highest educational degree; } 1=\text { low, } 2=\text { modest, } 3= \\
\text { high (Source: Vox-Data) }\end{array}$ \\
\hline Political ideology & $\begin{array}{l}\text { Self-placement on the left-right scale ranging from } 0=\text { far left to } 10 \\
\quad=\text { far right }(\text { Source: Vox-Data) }\end{array}$ \\
\hline \multicolumn{2}{|r|}{ - } \\
\hline $\begin{array}{l}\text { Percentage of } \\
\text { Catholics }\end{array}$ & $\begin{array}{l}\text { Percentage of Catholics of all religious adherents in Switzerland } \\
\text { (Source: Federal Office of Statistics) }\end{array}$ \\
\hline $\begin{array}{l}\text { Mean church } \\
\text { attendance }\end{array}$ & $\begin{array}{l}\text { Aggregated values for regularity of church attendance ranging from } \\
1=\text { "once a week" to } 5=\text { "never" (Source: Vox-Data) }\end{array}$ \\
\hline Urban area & $0=$ rural area, $1=$ urban area $($ Source: Vox-Data $)$ \\
\hline Linguistic region & $1=$ German, $2=$ French, $3=$ Italian $($ Source: Vox-Data) \\
\hline \multicolumn{2}{|l|}{ Referendum level } \\
\hline Year & Year vote took place (1993-2008) (Source: Vox-Data) \\
\hline Issue dimension & $\begin{array}{l}\text { Issue of vote/referendum: } 1=\text { genetic engineering, } 2=\text { addictive } \\
\text { behavior, } 3=\text { sexuality (Source: Vox-Data) }\end{array}$ \\
\hline $\begin{array}{l}\text { Christ-Democratic } \\
\text { Popular Party vote } \\
\text { recommendation }\end{array}$ & $\begin{array}{l}1=\text { liberal vote recommendation, } 0=\text { restrictive vote } \\
\text { recommendation }(\text { Source: Vox-Data) }\end{array}$ \\
\hline
\end{tabular}

